\title{
WORKING PAPER NO. 03-22/R MONETARY POLICY, OIL SHOCKS, AND TFP: ACCOUNTING FOR THE DECLINE IN U.S. VOLATILITY
}

\author{
Sylvain Leduc and Keith Sill* \\ Federal Reserve Bank of Philadelphia
}

*Corresponding author: Keith Sill, Research Department, Federal Reserve Bank of Philadelphia, Philadelphia, PA 19106, USA; telephone: 215-574-3815; fax: 215-5744364; e-mail: keith.sill@phil.frb.org

We thank John Leahey, Frank Schorfheide, Satyajit Chatterjee, Mike Dotsey, Luca Dedola, and seminar participants at the 2003 Society for Economic Dynamics meetings for their comments. This paper supercedes Working Paper No. 03-22. The views expressed here are those of the authors and not necessarily those of the Federal Reserve Bank of Philadelphia or the Federal Reserve System. 


\begin{abstract}
We use an equilibrium model to assess the importance of monetary policy for the decline in U.S. inflation and output volatility that has occurred since the mid-1980s. Our principal finding is that the change in monetary policy accounted for about 45 percent of the decline in inflation volatility but only 5 percent to 11 percent of decline in real output volatility. The model attributes most of the output volatility decline to smaller TFP shocks. We also calculate how much volatility would have declined had monetary policy been set optimally.
\end{abstract}




\section{Introduction}

The volatility of the U.S. economy since the mid-1980s is much lower than it was during the prior 20-year period. The proximate causes of the increased stability and their relative importance remain unsettled, but the sharpness of the volatility decline and its timing has led authors such as Taylor (2000) to argue that a sudden shift in monetary policy is a prime candidate. Many studies in the economic volatility literature date the break in real output growth volatility around 1984, some four years after the beginning of the Volcker chairmanship of the FOMC. ${ }^{1}$ A growing body of research indicates that systematic monetary policy changed significantly with the onset of the Volcker chairmanship. This apparent change in policy toward a more aggressive inflation-fighting stance could, in turn, have played a role in reducing the volatility of the economy post- $1984 .^{2}$

Recent work by Boivin and Giannoni (2003) argues that improved monetary policy has been more stabilizing for the economy both because of the way it has responded to shocks and by ruling out non-fundamental fluctuations. Their estimated structural models imply that the reduced effect of monetary policy shocks in the post-1980 period is almost entirely explained by an increase of the Fed's responsiveness to inflation and output. On the other hand, the VAR analysis in Stock and Watson (2002, 2003), Ahmed,

\footnotetext{
${ }^{1}$ See Kim and Nelson (1999), McConnell and Perez-Quiros (2000), Stock and Watson (2002).

${ }^{2}$ See Clarida, Galí, and Gertler (2000), Orphanides (2001), Lubick and Schorfeide (2002), Boivin and Giannoni (2003). For an alternative view see Sims and Zha (2002).
} 
Levin, and Wilson (2002), and Primiceri (2003) indicates that improved monetary policy played little role in the moderation of output volatility, though it perhaps played a role in lowering the volatility of inflation. ${ }^{3}$ These studies tend to indicate that smaller shocks are the principal cause of the moderation in U.S. economic volatility. ${ }^{4}$ In related work, Galí, López-Salido, and Vallés (2003) examine the Fed's systematic response to technology shocks and its implication for hours, output, and inflation. They find significant differences in the Fed's response pre-79 and post-79, and that post-79 policy is close to optimal.

We contribute to the debate on the importance of monetary policy for the decline in U.S. volatility by analyzing the volatility consequences of alternative systematic policy rules, including optimal policy, in a calibrated stochastic dynamic general equilibrium model. The exercise allows us to quantify the relative contributions of monetary policy and exogenous shocks such as TFP and oil supply to the postwar volatility pattern for U.S. output and inflation. The framework of our analysis is a standard sticky-price, dynamic equilibrium model in which monopolistically competitive firms use capital,

\footnotetext{
${ }^{3}$ Stock and Watson (2003) investigate counterfactuals in four small macroeconomic models and find that improved monetary policy accounts for less than 10 percent of the decline in output volatility post-1984. The models do suggest, though, that improved policy helps bring down the variance of inflation. Primiceri (2003) estimates a time-varying structural VAR and finds that though the systematic component of monetary policy changed post-1980, the change had a negligible effect on inflation and unemployment.

${ }^{4}$ Blanchard and Simon (2001) also argue that the principal reason for a less volatile U.S. economy is that it has been hit by smaller shocks.
} 
labor, and oil to produce goods. Historical monetary policy is assumed to have followed a Taylor-type rule, which is parameterized using coefficients estimated by Clarida, Galí, and Gertler (2000) and Orphanides (2001).

Boivin and Giannoni (2003) document that the monetary transmission mechanism appears to have changed when a comparison is made between pre-79 and post-79 data. They trace most of the change in the transmission mechanism to a change in the monetary policy rule rather than to a change in private-sector behavior. Our exercise builds on that finding by examining models in which the only parameters that vary across samples are those that govern the behavior of monetary policy. Measured historical shocks are used, rather than estimated shock processes and distributions, to simulate the model and explore counterfactuals. We assess the relative contributions of shocks and monetary policy to the decline in volatility since 1984 . We also investigate implied output and inflation volatility assuming monetary policy was set optimally over the postwar period. To our knowledge, this paper is one of the first to solve for optimal monetary policy in a sticky-price model with time-varying capital. Schmitt-Grohé and Uribe (2004) and Kollman (2003) examine welfare-maximizing monetary policies in a class of simple, implementable rules in models with endogenous capital accumulation. Our analysis does not restrict monetary policy to follow simple Taylor-type rules. ${ }^{5}$

Our principal finding is that the change in monetary policy played a relatively small role in the postwar volatility decline, accounting for 5 percent to

\footnotetext{
${ }^{5}$ Erceg, Henderson, and Levin (2000) solve for optimal monetary policy in a model with a fixed aggregate capital stock.
} 
11 percent of the drop in the standard deviation of real output. The model attributes most of the output volatility decline to smaller TFP shocks. Negative oil shocks do lead to significant downturns in real output in the model, but the pattern of exogenous shocks post- 84 is not different enough from the pre-79 pattern to play a meaningful role in lowering output volatility. ${ }^{6}$ We do find, however, that monetary policy played a significant role in stabilizing inflation, accounting for about 47 percent of the decline in its volatility. In the counterfactual optimal monetary policy specification, real output volatility would have been somewhat lower, and inflation volatility dramatically lower, than what was observed in the postwar data.

The paper is organized as follows. Section 2 describes some facts about the recent volatility decline for the U.S. economy. Section 3 presents the model; section 4 describes the optimal monetary policy problem; and sections 5 and 6 discuss calibration and simulation results. Section 7 concludes.

\section{Volatility Facts}

The facts we wish to account for are the volatility patterns of output and inflation for the postwar U.S. economy. Table 1 shows the standard deviations of quarterly real GDP growth and GDP deflator inflation by decades, as well as for samples with breakpoints in 1979Q4 and 1984Q1.

What stands out for both output growth and inflation volatility are the

\footnotetext{
${ }^{6}$ Leduc and Sill (2004) use a similar model framework to study the impact of oil shocks on the economy under a variety of monetary policy rules.
} 
low values of the 1990s, both of which are about half the level achieved in the 1970s and 1980s. Several studies have identified a breakpoint in real output growth volatility around 1984Q1. The table shows that, using that break date, output growth volatility dropped by about half in the post-1984Q1 sample. For inflation, the 1984 break date shows a much less dramatic decline. If the sample is split at 1979Q3, corresponding to a commonly determined monetary policy break date, inflation is seen to decline about 0.15 percentage point. Clearly though, inflation volatility in the 1990s was a good bit lower than over the preceding decades.

As an alternative way of looking at the data, we show time-series plots for rolling standard deviations of HP-filtered real GDP and HP-filtered GDP deflator inflation in Figures 1 and 2. For real GDP, a large drop in volatility occurs in the early 1980s. A similar drop in volatility occurs for inflation, though inflation volatility was also low prior to its run-up in the 1970s.

The volatility of real GDP growth dropped almost 50 percent, and inflation volatility dropped about 30 percent. The way in which the early 1980s recessions are included in the subsamples has implications for the magnitude of calculated volatility. In the analysis below, we follow the literature that puts the volatility break datr at the first quarter of 1984, which occurs about four years after the shift in monetary policy regime. 


\section{Model}

The baseline model framework is a standard sticky-price environment with monopolistically competitive firms. To investigate the contribution of oil shocks to economic volatility, we include an energy sector in the model. The model also has variable capital utilization, which appears to be an empirically important element in calculating an exogenous measure of TFP (see, e.g., Paquet and Robidoux (2001)).

The model is similar to that in Ireland (2001) with an energy sector modeled as in Atkeson and Kehoe (1999). The economy consists of a representative household, representative finished-goods-producing firm, a continuum of intermediate goods-producing firms indexed by $i \in[0,1]$, and a central bank. Time is discrete and is indexed by $t=0,1,2, \ldots$ Each producer of intermediate goods produces a distinct good, indexed by $i$. The structure is symmetric, so the intermediate goods sector can be modeled as a representative firm that produces a generic intermediate good $i$.

The representative household has preferences over consumption and hours worked:

$$
E_{0} \sum_{t=0}^{\infty} U\left(c_{t}, h_{t}\right)
$$

The household must use cash to finance consumption and faces the cash-inadvance constraint:

$$
P_{t} c_{t} \leq M_{t}
$$

The household earns labor income $W_{t} h_{t}$ and receives a nominal dividend $D_{t}$ from the intermediate-goods-producing firm that it owns. It also gets a lump 
sum transfer $T_{t}$ from the central bank. The household's budget constraint is:

$$
c_{t}+\frac{M_{t+1}}{P_{t}} \leq \frac{M_{t}+T_{t}+W_{t} h_{t}+D_{t}}{P_{t}}
$$

The household chooses $c_{t}, M_{t+1}, h_{t}$ to maximize (3.1) subject to the cashin-advance constraint (3.2) and the budget constraint (3.3). Let $\lambda$ be the multiplier on the household's budget constraint (3.3) and $\lambda^{m}$ be the multiplier on the cash-in-advance constraint. The first-order conditions for the household optimization problem in this model are well known but are reproduced to aid in characterizing the optimal policy problem in Section 4:

$$
\begin{aligned}
u_{c}\left(c_{t}, h_{t}\right)-\lambda_{t}-\lambda_{t}^{m} & =0 \\
-u_{h}\left(c_{t}, h_{t}\right)+\lambda_{t} \frac{W_{t}}{P_{t}} & =0 \\
-\frac{\lambda_{t}}{P_{t}}+\beta E_{t}\left(\frac{\lambda_{t+1}^{m}}{P_{t+1}}+\frac{\lambda_{t+1}}{P_{t+1}}\right) & =0
\end{aligned}
$$

Equation (3.4) characterizes the household consumption choice, equation (3.5) characterizes the choice of labor effort, and equation (3.6) characterizes the choice of money holdings.

The representative finished-goods-producing firm produces output $y_{t}$ using as inputs the output $y_{t}(i)$ of each intermediate- goods-producing firm. Each input is purchased at price $P_{t}(i)$. The technology for producing the final good is given by:

$$
Y_{t}=\left[\int_{0}^{1} y_{t}(i)^{\frac{\theta-1)}{\theta}} d i\right]^{\frac{\theta}{\theta-1}} \geq y_{t}
$$

with $\theta>1$. Profit maximization implies the demand for each input:

$$
y_{t}(i)=\left[\frac{P_{t}(i)}{P_{t}}\right]^{-\theta} y_{t}
$$


while the zero profits condition in the final goods sector gives the aggregate price index as:

$$
P_{t}=\left[\int_{0}^{1} P_{t}(i)^{1-\theta} d i\right]^{\frac{1}{1-\theta}}
$$

As in Atkeson and Kehoe (1999), the representative intermediate-goodsproducing firm combines capital services $f$ and labor to produce good $i$ according to the Cobb-Douglas technology:

$$
y_{t}(i) \leq z_{t} f\left(u(i)_{t}, k_{t}(i), e_{t}(i)\right)^{v_{g}} h_{t}(i)^{1-v_{g}}
$$

where $z_{t}$ is an exogenous productivity shock and $u_{t}(i)$ is a capital utilization rate chosen by the firm. Capital accumulation is given by $k_{t+1}(i)=I_{t}(i)+$ $\left(1-\delta\left(u_{t}\right)\right) k_{t}(i)$. The rate of capital depreciation depends on how intensively capital is utilized:

$$
\delta\left(u_{t}\right)=\frac{u_{t}^{\zeta}}{\zeta}
$$

with $\zeta>1$.

Capital services are produced by combining capital, utilization, and energy (oil) $e_{t}$ according to the technology:

$$
f=\left[v_{f}\left(u_{t}(i) k_{t}(i)\right)^{1-a}+\left(1-v_{f}\right) e_{t}(i)^{1-a}\right]^{\frac{1}{1-a}}
$$

The firm is assumed to face a quadratic cost of adjusting its price:

$$
A C_{t}(i)=\frac{\phi}{2}\left[\frac{P_{t}(i)}{P_{t-1}(i)}-1\right]^{2} y_{t}(i)
$$

The intermediate-goods-producing firm chooses labor, capital, utilization, and energy to maximize the present discounted value of its cash flow:

$$
E \sum_{t=0}^{\infty} \beta^{t} \lambda_{t} \frac{D_{t}(i)}{P_{t}}
$$


where:

$$
D_{t}(i)=P_{t}(i) y_{t}(i)-W_{t} h_{t}(i)-P_{t} I_{t}(i)-P_{t}^{e} e_{t}(i)-P_{t} A C_{t}(i)
$$

subject to constraints (3.8) and (3.10). Let $\lambda^{f}$ be the multiplier on constraint (3.10). The first-order conditions for the firm's optimization are:

$$
\begin{gathered}
-\lambda_{t}+E_{t} \beta\left[\lambda_{t+1}\left(1-\delta\left(u_{t+1}\right)\right)+\right. \\
\left.\lambda_{t+1}^{f} v_{g} z_{t+1} f_{k}\left(u_{t+1}, k_{t+1}, e_{t+1}\right)^{v_{g}-1} h_{t+1}^{1-v_{g}}\right]=0 \\
-\lambda_{t} \frac{W_{t}}{P_{t}}+\lambda_{t}^{f} z_{t}\left(1-v_{g}\right) f\left(u_{t}, k_{t}, e_{t}\right)^{v_{g}} h_{t}^{-v_{g}}=0 \\
-\lambda_{t} \delta_{u}\left(u_{t}\right) k_{t}+\lambda_{t}^{f} z_{t} v_{g} f_{u}\left(u_{t}, k_{t}, e_{t}\right)^{v_{g}-1} h^{1-v_{g}}=0 \\
-\lambda_{t} \frac{P_{t}^{e}}{P_{t}}+\lambda_{t}^{f} z_{t} v_{g} f_{e}\left(u_{t}, k_{t}, e_{t}\right)^{v_{g}-1} h_{t}^{1-v_{g}}=0 \\
\lambda_{t}(1-\theta)\left(\frac{P_{t}(i)}{P_{t}}\right)^{-\theta} \frac{y_{t}}{P_{t}}-\lambda_{t} \phi\left(\frac{P_{t}(i)}{P_{t-1}(i)}-1\right) \frac{y_{t}}{P_{t-1}(i)}+ \\
\lambda_{t}^{f} \theta\left(\frac{P_{t}(i)}{P_{t}}\right)^{-\theta-1} \frac{y_{t}}{P_{t}}+\beta \phi E_{t} \lambda_{t+1}\left(\frac{P_{t+1}(i)}{P_{t}(i)}-1\right) \frac{y_{t+1} P_{t+1}(i)}{P_{t}(i)^{2}}
\end{gathered}
$$

Equation (3.16) is the first-order condition for the firm's choice of capital while equation (3.17) is the optimality condition for labor input. Equation (3.18) governs the optimal choice of capital utilization. Equation (3.19) is the optimality condition for energy input, while (3.20) is the condition describing the firm's optimal pricing decision.

The supply of oil available to the economy is assumed exogenous. We interpret this as oil being imported from a cartel such as OPEC. In equilibrium, the price of oil adjusts to equate demand and supply.

We solve and simulate the model under a variety of systematic monetary policy rules. We assume that the historical monetary policy can be charac- 
terized by a Taylor rule in which the central bank sets the nominal interest rate $R_{t}$ as a function of inflation and output.

$$
R_{t}=\rho R_{t-1}+\beta_{\pi}(1-\rho)\left(E_{t} \pi_{t+1}-\pi^{*}\right)+\gamma(1-\rho)\left(y_{t}-y_{t}^{*}\right) .
$$

We will also solve and simulate the model assuming that monetary policymakers can commit to an optimal policy. This allows us to compare the volatility of the economy under the estimated Taylor rules to the volatility under optimal policy.

\section{Optimal Monetary Policy}

Optimal monetary policy is calculated by choosing a money growth rate that maximizes agents' welfare subject to the first-order conditions for the household and the firm and the economy-wide resource constraint. We follow an approach similar to that in Khan, King, and Wolman (2003) and form 
the Lagrangian:

$$
\begin{gathered}
\mathcal{L}=U\left(c_{t}, h_{t}\right)+\psi_{1, t} \lambda_{t}- \\
\psi_{1, t-1}\left[\lambda_{t}\left(1-\delta\left(u_{t}\right)\right)+\lambda_{t}^{f} v_{g} z_{t} f_{k}\left(u_{t}, k_{t}, e_{t}\right)^{v_{g}-1} h_{t}^{1-v_{g}}\right]+ \\
\psi_{2, t}\left[U_{h}\left(c_{t}, h_{t}\right)-\lambda_{t}^{f} z_{t}\left(1-v_{g}\right) f\left(u_{t}, k_{t}, e_{t}\right)^{v_{g}} h_{t}^{-v_{g}}\right]+ \\
\psi_{3, t}\left[y_{t}-c_{t}-I_{t}-\frac{\phi}{2}\left(\frac{P_{t}}{P_{t-1}}-1\right)^{2}-\frac{P_{t}^{e}}{P_{t}} e_{t}\right]+ \\
\psi_{4, t-1}\left[\phi \lambda_{t}\left(\frac{P_{t}}{P_{t-1}}-1\right) \frac{y_{t} P_{t}}{P_{t-1}^{2}}+\right. \\
\psi_{4, t}\left[(1-\theta) \lambda_{t} \frac{y_{t}}{P_{t}}-\phi \lambda_{t}\left(\frac{P_{t}}{P_{t-1}}-1\right) \frac{y_{t}}{P_{t-1}}+\theta \lambda_{t}^{f} \frac{y_{t}}{P_{t}}\right]+ \\
\psi_{5, t-1} U_{c}\left(c_{t}, h_{t}\right) \frac{P_{t-1}}{P_{t}}-\psi_{5, t} \lambda_{t}+ \\
\psi_{6, t}\left[\lambda_{t} \delta_{u}\left(u_{t}\right) k_{t}-\lambda_{t}^{f} z_{t} v_{g} f_{u}\left(u_{t}, k_{t}, e_{t}\right)^{v_{g}-1} h_{t}^{1-v_{g}}\right]+ \\
\psi_{7, t}\left[\frac{M_{t+1}}{M_{t}}-\beta\right]+\psi_{8, t}\left[e_{t}^{s}-e_{t}\right]
\end{gathered}
$$

Note the added constraint that money growth be greater than or equal to the discount factor $\beta$ and the imposition of the equilibrium condition that all intermediate-goods-producing firms charge the same price, which is equal to the aggregate price index. The supply of energy $e_{t}^{s}$ is assumed to be supplied exogenously, and the price of energy adjusts to equate demand and supply.

The aggregate price level $P_{t}$ is deflated by the money supply $M_{t}$ to get a stationary representation of the system. We assume the cash-in-advance constraint binds and use it to substitute for $P_{t} / M_{t}$ in the Lagrangian. Define $g_{t}=M_{t+1} / M_{t}$. Derivatives of the Lagrangian then are taken with respect to $c_{t}, h_{t}, k_{t+1}, g_{t}, \lambda_{t}, \lambda_{t}^{f}, u_{t}, e_{t}, \psi_{1, t}, \psi_{2, t}, \psi_{3,5}, \psi_{4, t}, \psi_{5, t}, \psi_{6, t}, \psi_{7, t}, \psi_{8, t}$. These firstorder conditions are then linearized around steady state, and the decision 
rule for optimal monetary policy is solved for using a linear system of equations. $^{7}$

\section{Calibration}

For the benchmark model, we use log preferences:

$$
E_{t} \sum_{t=0}^{\infty}\left(\ln c_{t}+\alpha \ln \left(1-h_{t}\right)\right)
$$

where $\alpha$ is chosen so that hours worked is 30 percent of the time endowment. The parameter that governs the elasticity of substitution between goods $\theta$ is chosen so that the markup of price over marginal cost is 11 percent, a value consistent with that in Basu and Fernald (1994). We set the parameter $\zeta$ in equation (3.11) so that steady-state depreciation is 0.025 . Values of all parameters used to calibrate the model are summarized in Table 2.

\footnotetext{
${ }^{7}$ We use Mathematica to take derivatives of the Lagrangian (4.1) and input the resulting analytical first-order conditions into Dynare to solve the model. We also solved the optimal policy problem using a second-order approximation, but found the results to be very similar to those found under the first-order approximation. For example, there is no difference in the implied standard deviation of inflation when the model is simulated under the first-order vs. second-order approximation. The difference in the simulated standard deviation of real output is about 0.01 percent when comparing the first- and second-order approximation solutions.
} 


\section{$5.1 \quad$ TFP Shocks}

TFP is an exogenous driving process for the model. To compute this shock we use series on the capital stock, oil use, hours worked, output, and the values for the parameters $v_{f}, v_{g}$. Following Burnside and Eichenbaum (1996), the optimality conditions (3.5) and (3.17-3.19) are used to solve for $u_{t}$ as a function of $k_{t}, h_{t}, e_{t}$ and $z_{t}$. The expression for the implied value of $u_{t}$ is then substituted into (3.10) to calculate the implied level of TFP. ${ }^{8}$

The capital stock series is measured as the net stock of nonfarm, nonresidential fixed assets and consumer durables. The aggregate hours series is constructed as average total nonfarm employment per quarter less employment in the gas and oil industries times average quarterly hours. The output measure is real quarterly GDP less farm and housing and ex oil production. The energy series is oil use by the private nonresidential sector and govern-

\footnotetext{
${ }^{8}$ Basu, Fernald, and Kimball (BFK 1997) construct a generalized Solow residual that allows for increasing returns, imperfect competition, and variable labor and capital input utilization rates. Their measure is available annually up to 1996. Our constructed TFP series, at an annual frequency, has a correlation of about 0.5 with the BFK measure. Unlike the BFK series, our TFP measure is predicted by the federal funds rate and so is not statistically exogenous. However, the BFK series is a problematic input for our model given that it accounts for, among other things, increasing returns to scale, which our model does not contain. In addition, at only an annual frequency, it would be problematic to construct accurate volatility measures for the post-1984 sample. For these reasons, we did not input the BFK series into our model.
} 
ment. ${ }^{9}$ We compute a labor share $s_{t}=1-v_{g}=0.67$ and an energy share $s_{e}=1-v_{f}=0.037$. When solving the model, we assume TFP follows an $\operatorname{AR}(1)$ process with correlation coefficient $\rho_{z}=0.95$.

We chose the parameter $a$ in equation (3.12) so that the short-run elasticity of substitution of energy use with respect to energy price is given by

$$
\eta_{s r}=\frac{-1}{\left(1-s_{e}\right) a+s_{e} b / s_{l}}
$$

matches the value of -0.333 used by Atkeson and Kehoe (1999).

\subsection{Price Adjustment}

Our quadratic price-adjustment cost specification implies the reduced form for inflation

$$
\pi_{t}=\beta E_{t} \pi_{t+1}+\lambda m c_{t}
$$

where $\lambda=(\theta-1) /\left(\phi \bar{\pi}^{2}\right), m c_{t}$ is the nominal marginal cost of production, and $\bar{\pi}$ is steady-state inflation. This is the same reduced form as that for a typical Calvo price-setting model, though in the Calvo model $\lambda=((1-\eta)(1-\beta \eta)) / \eta$ with $\eta$ the fixed probability that a firm must keep its price unchanged in any given period (see Galí and Gertler (1999)). In our baseline parameterization, we choose a frequency of price-adjusment $\eta$ to:

$$
\min _{\eta}\left\{0.5\left|\sigma_{\pi}^{79}-\hat{\sigma}_{\pi}^{79}\right|+0.5\left|\sigma_{\pi}^{84}-\hat{\sigma}_{\pi}^{84}\right|\right\}
$$

\footnotetext{
${ }^{9}$ Our data on energy use come from the Energy Information Administration (EIA). The EIA does not compile data on energy use for the private and government sectors separately.
} 
where $\sigma_{\pi}^{j}$ is inflation volatility measured from the data for subsample $j$ and $\hat{\sigma}_{\pi}^{j}$ is inflation volatility measured using simulated data from the model for subsample $j$. The minimization is conditional on the values chosen for all other parameters of the model. For the benchmark, the minimization gives $\eta=0.28$, which means that, on average, firms adjust price every 3.5 months. This price-adjustment frequency is similar to the median frequency of price adjustment of 4.3 months reported in Bils and Klenow (2002). The estimated value of $\eta$ in turn implies two values of $\phi$, since steady-state inflation pre-79 is different from steady-state inflation post-84. The pre-79 model is calibrated with $\phi=4.75$, while the post-84 model is calibrated with $\phi=4.74$.

As a robustness check, we will also consider a high price adjustment cost specification in which the frequency of price adjustment is 12 months.

\subsection{Oil Sector}

Oil supply is treated as exogenous in our simulations, and price is allowed to adjust to changes in supply. To measure exogenous supply, we use Hamilton's (2000) quantitative oil dummy variable that identifies historical episodes in which military conflict led to disruptions in world oil supply. The identified episodes are listed in Table 3.

We treat quantity, rather than price, as exogenous because of the sharp change in the oil market over the postwar period. As argued in Hamilton (1983, 1985), there is evidence that the price of oil can reasonably be argued to be exogenous during the period 1948-1972. Since the end of the 1970s, 
though, the time series properties of the price of oil are much different and the price appears to be much more affected in the short run by world demand conditions. These facts pose a challenge for a model that assumes exogenous oil prices when accounting for the change in economic volatility over the postwar era. Our solution of treating quantity as exogenous is not without problems though-the method allows domestic TFP to affect the price of oil prior to 1973. We are assuming that treating quantity, rather than price, as exogenous leads to more consistent treatment of the oil market pre-1973 and post-1973.

In the model simulations, then, we assume that the quantity of oil used in the economy is constant except for the disruptions identified by Hamilton (2000). The quantity disruptions are assumed to last for one quarter, after which time the oil quantity series returns to its baseline level. When solving the model, we approximate an i.i.d. process by modeling the quantity of oil supply as an $\mathrm{AR}(1)$ process with autoregressive coefficient $\rho_{\text {oil }}=0.95$.

\subsection{Monetary Policy}

In characterizing historical monetary policy, we assume that systematic policy follows a Taylor rule that sets the short-term nominal interest rate as a function of the output gap and expected inflation. We parameterize the policy rule using the estimates in Clarida, Galí, and Gertler (2000) and Orphanides (2001). Clarida et al. estimate a forward-looking rule on GDP deflator inflation and the CBO output gap. Their estimates suggest the Fed 
increased the nominal funds rate less than one-for-one with expected inflation in the pre-1979Q2 sample, which leads to indeterminacy in their model. The post-1979 estimates show that the Fed raised the funds rate more than one-for-one with expected inflation.

Orphanides (2001) also estimates a forward-looking Taylor rule but uses real-time data on forecasts of GDP deflator inflation and the output gap made by Federal Reserve Board staff for FOMC meetings. His estimates suggest that the Fed had a strong reaction to inflation forecasts both before and after 1979. The weight on the output gap in rules estimated using pre-1979 data is higher because of real-time uncertainty about the level of potential GDP. Federal Reserve Board staff forecasts did not correctly perceive that potential output growth slowed in the early 1970s, and so the perceived output gap was larger than the actual output gap.

Table 4 shows the policy rule parameters under Orphanides and CGG. We use the Orphanides policy rule estimate for the pre-79 period and the CGG estimate to calibrate the post- 84 rule. We did not use the CGG rule pre-79 in the baseline because it leads to indeterminacy, and we do not want our baseline case to be one where sunspot equilibria are possible. ${ }^{10}$ We chose the CGG rule for our post-84 subsample because the sample period over which they estimated their rule lines up more closely with our sample (Orphanides (2001) estimates his rule pre-79 and post-79).

The level of potential output used to calculate the output gap in our sim-

\footnotetext{
${ }^{10}$ In the sensitivity analysis section of the paper, we do, however, consider a model that has a much lower weight on expected inflation.
} 
ulations is the level of output given by a nonmonetary, flexible-price version of the model under the baseline calibration. The state variables used to calculate potential output are those that evolve under the assumption that the economy is always in a nonmonetary, flexible-price equilibrium.

\section{Simulations}

The model is simulated over the periods 1964Q1 to 1979Q2 and 1984Q2 to 1999Q3. We chose to end the sample in 1999Q3 so that our two subsamples are of equal length, which makes comparison between them straightforward. We drop the period 1979Q3 to 1984Q4 from our analysis for two reasons. First, many studies date a break in monetary policy at the beginning of the Volcker regime in October 1979. At the same time, statistical evidence puts the break in real output volatility around 1984Q1, and as seen in Table 1, whether or not the 1980-1983 data are included in the volatility calculations has a significant effect on the resulting statistics. Second, Sims and Zha (2002) argue that the episode from 1980 to 1982 appears to be different in terms of monetary policy, and that it is not the case that there was a dramatic shift in policy between the 1960-78 period and the 1983-2000 period. These timing issues led us to drop the 1980-1983 episode from the analysis.

The models for which monetary policy is assumed to follow a Taylor rule are linearized and solved using the method described in King and Watson (1998). Solutions are found for the pre-79 and post-84 calibrations. The models are then simulated assuming the pre- 79 and post- 84 economies are 
independent. ${ }^{11}$ Thus, we implicitly assume that households in the pre-79 subsample thought the monetary policy rule would forever stay at its pre-79 calibration. Transition dynamics between the regimes are not modeled.

We first examine the model's implications for real output and inflation volatility in the pre-79 and post-84 periods. We then examine the contribution of policy and shocks to the decline in output volatility.

\subsection{Output and Inflation Volatility Under the Bench- mark}

We first consider the model's implications for output and inflation volatility in the pre-79 and post-84 periods.

Panel A of Table 5 shows that the benchmark model overpredicts the decline in real output volatility. In the data, the standard deviation of real output falls 45 percent, from 2.11 percent to 1.16 percent. The benchmark model implies a fall in real output volatility of 55 percent, from 2.58 percent to 1.16 percent. The benchmark specification overpredicts the standard deviation of real output by about 20 percent in the pre-1979 period but matches the standard deviation of real output in the post-1984 sample.

Panel B of Table 5 shows that the benchmark specification is close to matching the standard deviation of inflation in the pre-79 period but underpredicts the standard deviation in the post-84 period. Consequently, the

\footnotetext{
${ }^{11}$ We detrend both actual and simulated data using the Hodrick-Prescott filter and calculate standard deviations of the cyclical components.
} 
model overpredicts the decline in inflation volatility. In the data, the volatility decline is 54 percent versus the 82 percent predicted by the model.

To help explain the intuition of the baseline model simulations, Figure 3 plots impulse responses for a TFP shock under the pre-79 and post-84 Taylor rule, as well as under optimal monetary policy. An increase in TFP initially raises output above its steady state and puts downward pressure on the rate of inflation. The post-84 Taylor rule places somewhat less weight on expected inflation and the output gap compared to the pre-79 policy rule (see Table 2), so money growth rises relatively less in order to offset the downward pressure on prices. Indeed, the increase in money growth is not enough to completely offset expected disinflation so that the nominal interest rate ends up falling. Under the pre-79 rule specification, policymakers respond more sharply to expected deviations in inflation by more sharply increasing the money growth rate, with the consequence that actual and expected inflation rise, as does the nominal interest rate. Under both rule specifications, inflation returns to near steady state within one period.

The post-84 policy rule economy shows a smaller impact response of output, consumption, and hours worked to a temporary increase in TFP. The post-84 policy rule dampens the impact response of inflation to the productivity shock and so minimizes the distortion arising from the price-adjustment cost. Under the pre-79 policy regime, the price level rises sharply on impact in response to the TFP shock, which leads to a larger effect on consumption (indeed an initial fall in consumption) because consumption is subject to the cash-in-advance constraint. In the post-84 policy regime, the price level 
falls more modestly on impact, and the decline in consumption is smaller. Consumption then rises above steady state in both policy regimes and is accompanied by a fall in investment.

The fact that output and hours rise more on impact under the pre-79 policy regime than under the post-84 policy regime can be accounted for by the relatively sharper rise in inflation under the pre-79 regime. The jump in inflation is a tax on household real balances that reduces household wealth. In response to the wealth reduction, households supply more labor effort. Higher TFP and increased labor effort also induce intermediate-goods firms to utilize capital more intensively.

The third column of Figure 3 shows the economy's response to a TFP shock under optimal monetary policy. For the most part, the response of output and inflation to a TFP shock under optimal monetary policy is similar to the response under the post-84 Taylor rule specification. Optimal policy attempts to keep inflation constant and so is consistent with the results in Khan, King, and Wolman (2003), who study optimal policy in a framework without capital. In response to downward pressure on inflation engendered by the rise in TFP, the money growth rate increases. With little change in actual or expected inflation, the nominal interest rate rises about as much as the real interest rate: optimal policy does not follow a Friedman rule that keeps the nominal interest rate near zero. As under the post-84 regime, consumption moves little on impact owing to the effect of the cash-in-advance constraint.

Table 6 shows the volatilities of output and inflation that are implied 
by the benchmark model under optimal monetary policy. As suggested by the impulse response analysis, optimal policy sets the variance of inflation to almost zero, so that the economy's sticky-price distortion is eliminated. Real output is more volatile under optimal policy than in the historical data for the pre-79 sample and slightly less volatile in the post-84 sample. Comparing the benchmark cases in Tables 5 and 6 , we see that optimal policy lowers the volatility of both output and inflation compared to Taylor rule specifications for pre-79 and post-84. Under optimal policy, the decline in the standard deviation of real output is about 50 percent and the decline in the standard deviation of inflation is about 55 percent.

\subsection{Contributions to the Decline in Output Volatility}

Table 7 shows the contribution of monetary policy, oil shocks, and TFP shocks to the decline in real output volatility. We measure these contributions as follows:

$$
\begin{aligned}
& \frac{\hat{\sigma}_{\text {oilicy,tfp } 84}^{\text {policy } 79}-\hat{\sigma}_{\text {oilis4,tfp } 84}^{\text {polic } 84}}{\sigma_{\text {oilicy,tfp } 79}^{\text {policy }}-\sigma_{\text {oilisy,tfp } 84}^{\text {policy }}} \quad \text { monetary policy } \\
& \frac{\hat{\sigma}_{\text {oil } 84, t f p 79}^{\text {policy } 84}-\hat{\sigma}_{\text {oil } 84, t f p 84}^{\text {policy } 84}}{\sigma_{\text {oil } 79, t f p 79}^{\text {policy } 79}-\sigma_{\text {oil } 84, t f p 84}^{\text {policy } 84}} \quad \text { TFP shocks } \\
& \frac{\hat{\sigma}_{\text {oilic9,tfp } 84}^{\text {policy } 84}-\hat{\sigma}_{\text {oilis4,tfp } 84}^{\text {policy } 84}}{\sigma_{\text {oilicy,tfp } 79}^{\text {policy }}-\sigma_{\text {oilicy,tfp } 84}^{\text {policy84 }}} \quad \text { oil quantity shocks }
\end{aligned}
$$


where, for example, $\hat{\sigma}_{\text {oil } 84, t f p 84}^{\text {policy } 79}$ is output volatility generated by the model when we feed in measured TFP for the post-84 period, measured oil quantity for the post-84 period, and use the pre-79 Orphanides monetary policy rule to solve the model. Variables without^'s are measured directly from the data. Note that the contributions do not sum to one. Our contribution measures follow those in Stock and Watson (2003) and isolate the effect of changing a single policy or shock sequence holding everything else constant.

Table 7a shows that, under the benchmark calibration, the change in monetary policy accounted for only about 6 percent of the decline in real output volatility. Oil quantity shocks do not contribute to the decline in volatility: they, in fact, raise real output volatility by a small amount (0.2 percent) in the post-84 sample. ${ }^{12}$ TFP shocks accounted for the lion's share of the volatility decline at about 91 percent. On the other hand, the change in policy regime appears to have played a large role in stabilizing inflation volatility: under the benchmark model, the change in systematic monetary policy accounted for about 47 percent of the decline in the standard deviation of inflation.

The impulse responses in Figure 3 bear out the finding that the change in systematic monetary policy is unlikely to have played much of a role in the volatility decline. The pre-79 and post-84 policy regimes show relatively small differences in the response of real variables to a productivity shock. Indeed, the impulse responses for real variables are not that different even when

\footnotetext{
${ }^{12}$ Oil prices are more variable in the post-79 data. Stock and Watson (2002) also find that oil shocks raised volatility in the post-1979 period relative to the pre-1979 period.
} 
compared to those under optimal monetary policy. The larger difference across policy regimes is in the behavior of inflation and the nominal interest rate. Inflation moves much more on impact in the pre-79 regime. Again, this is because under the benchmark policy rule specification, policymakers respond more sharply to expected disinflation in the pre-79 regime, with the consequence that current inflation jumps sharply.

\subsection{Sensitivity Analysis}

We check the sensitivity of our results by analyzing several different specifications of the model. These alternative specifications are described in Table 8. The parameters that vary across specifications are listed in the columns of the table. For each model specification, the adjustment cost parameter was chosen according to (5.4). All other parameters are the same as in the benchmark calibration reported in Table 2. For the habit persistence specification we choose the weight on lagged consumption so that it matches the estimate in Fuhrer (2000).

The parameterization of our benchmark model puts a greater weight on inflation in the monetary policy rule pre- 79 relative to post- 84 . This is counter to a widely held belief that monetary policy was more accommodative of inflation in the pre-Volcker period than after. For example, the policy rule estimated in Clarida, Galí, and Gertler (2000) over 1969Q2-1979Q2 leads to indeterminacy because of the low estimated weight on expected inflation. To investigate the implications of our model for output and inflation under an 
easy-inflation monetary policy rule, we use an alternative parameterization of the CGG pre-79 rule. We use their estimated values of the coefficient on the output gap and persistence but raise the estimated weight on expected inflation just enough to get a determinate solution. The rule parameterization for the pre-79 period is reported in the fifth row of Table 2. We refer to this parameterization as the "low inflation weight" case, which uses a "modified CGG rule" as reported in Table 8.

Figure 4 shows impulse responses to a TFP shock under the modified CGG rule case. With a low weight on expected inflation, a rise in TFP leads to sharply lower inflation on impact. Low inflation leads to a positive wealth effect on consumption and leisure that raises them above steady state on impact. Hours fall enough that output declines on impact, before rising above steady state. Inflation remains below steady state, leading to a drop in the nominal interest rate. Thus, under the modified CGG policy rule, positive TFP shocks lead to an impact decline in real output and inflation.

The performance of the alternative specifications and the implied contributions of monetary policy and exogenous shocks are reported in Tables 5, 6, and 7. Table 5, panel A, reveals that the alternative specifications all overpredict the decline in real output volatility, largely because they overpredict volatility in the pre-79 sample. The model with habit persistence generally shows the lowest levels of volatility pre-79 and post-84 because, with habit persistence, consumption is smoothed, and since output is demand determined, output volatility is lower.

Inflation volatility results for the alternative specifications are reported in 
Table 5, panel B. There is more variation across models in their prediction of inflation volatility than in their prediction of real output volatility. The high price-adjustment cost specification and the sunspot specification give especially low predictions for inflation volatility because the implied frequency of price adjustment in these models is low-on the order of 30 percent of firms adjusting prices every quarter. The introduction of habit persistence or high markups has little effect on the standard deviation of inflation implied by the model.

Table 6 shows that, when monetary policy is set optimally, there remains little variation across specifications in the simulated standard deviation of real output. The specifications continue to overpredict volatility in the pre79 period and underpredict it in the post- 84 sample. Inflation volatility is set close to zero across the specifications (the numbers in Table 6 are in percentage terms). The high-price adjustment cost specification comes closest to achieving complete price stability.

From the sensitivity analysis, we conclude that alternative parameterizations have a relatively small impact on the amount of real output volatility generated by the model. More significant are the effects on simulated inflation volatility. However, the most reasonable parameterizations give quite similar results in generating inflation volatility close to that of the pre-79 period and somewhat below that of the post-84 period. 


\section{Conclusion}

We used a structural model to assess the relative contributions of monetary policy, TFP shocks, and oil shocks to the decline in volatility of U.S. real output. We find that monetary policy played a relatively small role in the decline in volatility of real output: on the order of 5-11 percent. Monetary policy did, however, account for about 47 percent of the decline in inflation volatility. Oil shocks played no role in lower output volatility. The paper finds evidence for the view that smaller shocks are the principal cause of the more stable real economy post-1984. We examined alternative specifications of the model that varied preferences and degree of nominal rigidity. The results are robust to these variations on the benchmark model.

We also calculate the counterfactual of postwar volatility under optimal monetary policy with commitment. We find that, relative to the estimated historical Taylor rules, optimal policy would have virtually eliminated inflation variability without having a substantial impact on real output volatility. Under optimal monetary policy, the standard deviation of real output declines a bit over 50 percent compared with 45 percent in the data. 


\section{References}

[1] Ahmed, S., Levin, A., Wilson, B., 2002. Recent U.S. macroeconomic stability: good policies, good practices, or good luck. Board of Governors of the Federal Reserve System, International Finance Discussion Paper No. 730 .

[2] Atkeson, A., Kehoe, P.J., 1999. Models of energy use: putty-putty versus putty-clay. American Economic Review, 89, 1028-1043.

[3] Basu, S., Fernald, J., 1994. Constant returns and small markups in U.S. manufacturing. Board of Governors of the Federal Reserve System International Finance Discussion Paper No. 483.

[4] Basu, S., Fernald, J., Kimball, M., 1997. Are technology improvements contractionary? University of Michigan.

[5] Bils, M., Klenow, P.J., 2002. Some evidence on the importance of sticky prices. NBER Working Paper No. 9069.

[6] Blanchard, O., Simon, J. 2001. The long and large decline in U.S. output volatility. Brookings Papers on Economic Activity 2001:1, 135-164.

[7] Boivin, J., Giannoni, M., 2003. Has monetary policy become more effective? NBER Working Paper No. 9459.

[8] Burnside, C., Eichenbaum, M., 1996. Factor-hoarding and the propagation of business-cycle shocks. American Economic Review 86, pp. 1154-1174. 
[9] Christiano, L.J., Gust, C.J, 1999. Taylor rules in a limited participation model, De Economist 147, 437-460.

[10] Clarida, R., Galí, J., Gertler, M., 2000. Monetary policy rules and macroeconomic stability: evidence and some theory. Quarterly Journal of Economics 115, pp. 147-180.

[11] Erceg, C., Henderson, D.W., Levin, A.T., 2000. Optimal monetary policy with staggered wage and price contracts. Journal of Monetary Economics 46, 281-313.

[12] Fuhrer, J.C., 2000. Habit formation in consumption and its implications for monetary-policy models. American Economic Review, 367-390.

[13] Galí, J., Gerlter, M., 1999. Inflation dynamics: a structural econometric analysis. Journal of Monetary Economics 44, 195-222.

[14] Galí, J., López-Salido, J.D., Vallés, J., 2003. Technology shocks and monetary policy: assessing the Fed's performance. Journal of Monetary Economics 50, 723-743.

[15] Hamilton, J.D., 1983. Oil and the macroeconomy since World War II. Journal of Political Economy 91, 228-248.

[16] Hamilton, J.D., 1985. Historical causes of postwar oil shocks and recessions. Energy Journal 6, 97-116.

[17] Hamilton, J.D., 2000. What is an oil shock? Working Paper No. 7755, National Bureau of Economic Research. 
[18] Ireland, P., 2001. Sticky-price models of the business cycle: specification and stability. Journal of Monetary Economics 47, 3-18.

[19] Khan, A., King, R.G., Wolman, A.L. 2003. Optimal monetary policy. Review of Economic Studies 70, 825-60.

[20] Kim, C.J., Nelson C.R., 1999. Has the U.S. economy become more stable? A Bayesian approach based on a Markov-switching model of the business cycle. The Review of Economics and Statistics 81, 608-616.

[21] King, R.G., Watson, M.W., 1998. The solution of singular linear difference systems under rational expectations. International Economic Review 39, 1015-1026.

[22] Kollman, R., 2003. Welfare maximizing fiscal and monetary policy rules. Manuscript, Center for Economic Policy Research.

[23] Leduc, S., Sill, K., 2004. A quantitative analysis of oil-price shocks, systematic monetary policy, and economic downturns. Journal of Monetary Economics forthcoming.

[24] Lubick, T., Schorfheide, F., 2002. Testing for indeterminacy: an application to U.S. monetary policy. University of Pennsylvania Working Paper.

[25] McConnell, M.M., Perez-Quiros, G., 2000. Output fluctuations in the United States: what has changed since the early 1980s. American Economic Review 90, 1464-1476. 
[26] Orphanides, A., 2001. Monetary policy rules, macroeconomic stability and inflation: a view from the trenches. Working Paper, Federal Reserve Board of Governors.

[27] Paquet, A., Robidoux, B., 2001. Issues on the measurement of the Solow residual and the testing of its exogeneity: evidence for Canada. Journal of Monetary Economics 47, 595-612

[28] Primiceri, G.E., 2003. Time varying structural vector autoregressions and monetary policy. Working Paper, Princeton University.

[29] Schmitt-Grohé, S., Uribe, M., 2004. Optimal simple and implementable monetary and fiscal rules. Manuscript, Duke University.

[30] Sims, C.A., Zha, T., 2002. Macroeconomic switching. Manuscript, Princeton University.

[31] Stock, J.H., Watson, M.W., 2003. Has the business cycle changed? Evidence and explanations, Manuscript prepared for Federal Reserve Bank of Kansas City Symposium "Monetary Policy and Uncertainty."

[32] Stock, J.H., Watson, M.W., 2002. Has the business cycle changed and why? NBER Macroeconomics Annual 2002, 159-218.

[33] Taylor, J.B., 2000. Remarks for panel discussion on recent changes in trend and cycle. SIEPR Conference. 
Table 1: std of quarterly real GDP growth and GDP deflator inflation

\begin{tabular}{|c|c|c|c|c|c|c|c|c|}
\hline & $60 \mathrm{~s}$ & $70 \mathrm{~s}$ & $80 \mathrm{~s}$ & $90 \mathrm{~s}$ & Pre-79 & Post-79 & Pre-84 & Post-84 \\
\hline GDP & 0.879 & 1.094 & 0.969 & 0.531 & 1.008 & 0.777 & 1.081 & 0.485 \\
Inf & 0.381 & 0.529 & 0.604 & 0.239 & 0.664 & 0.538 & 0.699 & 0.250 \\
\hline
\end{tabular}

Table 2: Benchmark model calibration

\begin{tabular}{|c|c|}
\hline Parameter & Value \\
\hline$\beta$ & 0.99 \\
\hline $\bar{\delta}$ & 0.025 \\
\hline$\theta$ & 10.091 \\
\hline$v_{g}$ & 0.33 \\
\hline$v_{f}$ & 0.963 \\
\hline$a$ & 3.0512 \\
\hline$\eta$ & 0.28 \\
\hline$\varepsilon_{s r}$ & -0.333 \\
\hline$e / k$ & 0.00497 \\
\hline$\rho_{z}$ & 0.95 \\
\hline$\rho_{\text {oil }}$ & 0.95 \\
\hline
\end{tabular}


Table 3: Hamilton (2001) Quantitative oil dummy Exogenous changes in world oil supply

\begin{tabular}{|c|c|c|}
\hline Date & Event & Drop in world production \\
\hline Nov. 1973 & Arab-Israeli War & $7.8 \%$ \\
Dec. 1978 & Iranian Revolution & $8.9 \%$ \\
Oct. 1980 & Iran-Iraq War & $7.2 \%$ \\
Aug. 1990 & Persian Gulf War & $8.8 \%$ \\
\hline
\end{tabular}

Table 4: Monetary policy rule parameterization $R_{t}=\rho R_{t-1}+\psi(1-\rho) E_{t}\left(\pi_{t+1}-\pi^{*}\right)+\gamma(1-\rho)\left(y_{t}-y_{t}^{*}\right)$

\begin{tabular}{|c|c|c|c|}
\hline Rule & $\rho$ & $\psi$ & $\gamma$ \\
\hline CGG: 69Q2-79Q2 & 0.68 & 0.83 & 0.27 \\
\hline CGG: 83Q1-96Q4 & 0.91 & 1.58 & 0.15 \\
\hline Orphanides: 66Q1-79Q2 & 0.70 & 1.64 & 0.57 \\
\hline Orphanides: 79Q3-95Q4 & 0.79 & 1.80 & 0.27 \\
\hline Modified CGG: 69Q2-79Q2 & 0.68 & 1.05 & 0.27 \\
\hline
\end{tabular}


Table 5: Output and Inflation Volatility (in \%)

\section{Pre-1979 Post-1984 Decline}

Panel A: Standard Deviation of Output

Data

1.16

$-45.0$

Models

Benchmark Model

Habit Persistence

High Markup

High Price-Adjustment Cost

Low Inflation Weight Pre-1979
2.58

2.49

2.49

2.58

2.58

Panel B: Standard Deviation of Inflation

Data

0.37

0.17

$-54.1$

Models

Benchmark Model

0.39

0.38

0.38

0.010

0.37

1.16

$-55.2$

1.04

$-58.2$

1.07

$-57.1$

$-54.5$

1.17

$-54.6$

Habit Persistence

High Markup

High Price-Adjustment Cost

Low Inflation Weight Pre-1979

$0.011 \quad 6.43$

0.01

$-96.8$ 
Table 6: Output and Inflation Volatility Under Optimal Policy (\%)

\section{Pre-1979 Post-1984}

Panel A: Standard Deviation of Output

Data

1.16

Models

Benchmark Model

2.36

1.12

Habit Persistence

2.31

1.10

High Markup

2.33

1.11

High Price-Adjustment Cost

Panel B: Standard Deviation of Inflation

Data

Models

Benchmark Model

$0.018 \quad 0.010$

Habit Persistence

0.055

0.031

High Markup

0.031

0.017

High Price-Adjustment Cost

0.001

0.0006 
Table 7: Contribution of Monetary Policy to the Decline in Inflation and Output Volatility (in \%)

\begin{tabular}{lccc}
\hline & Policy & Oil Shocks & TFP \\
\hline Panel A: Output & & & \\
Models & & & \\
$\quad$ Benchmark Model & 5.6 & -0.2 & 90.6 \\
Habit Persistence & 11.2 & -0.1 & 82.8 \\
High Markup & 8.5 & -0.1 & 85.9 \\
High Price-Adjustment Cost & 3.7 & -0.2 & 92.8 \\
Low Inflation Weight Pre-1979 & 11.7 & 0.2 & 92.2 \\
& & & \\
Panel B: Inflation & & & \\
Models & & & \\
Benchmark Model & & & \\
Habit Persistence & 46.8 & -0.02 & 16.5 \\
High Markup & 42.8 & 0.14 & 24.6 \\
High Price-Adjustment Cost & -796.5 & 10.9 & 2038.0 \\
Low Inflation Weight Pre-1979 & 52.4 & 0.05 & 3.6 \\
\hline
\end{tabular}


Table 8. Sensitivity Analysis Model Specifications

\begin{tabular}{|c|c|c|c|c|}
\hline Model Specification & Preferences & Price Adjustment Cost & Markup & Policy Rule \\
\hline Benchmark & $\ln c_{t}+1.76 \ln \left(1-h_{t}\right)$ & $\begin{array}{l}\eta=0.28 \\
\phi^{\text {pre } 79}=4.75, \phi^{\text {post } 79}=4.74\end{array}$ & $\frac{\theta}{\theta-1}=1.11$ & $\begin{array}{l}\text { Pre-79: Orphanides } \\
\text { Post-84: CGG }\end{array}$ \\
\hline Habit Persistence & $\begin{array}{l}\ln \left(c_{t}-0.8 c_{t-1}\right)+ \\
1.83 \ln \left(1-h_{t}\right)\end{array}$ & $\begin{array}{l}\eta=0.32 \\
\phi^{\text {pre79}}=5.92, \phi^{\text {post79}}=6.00\end{array}$ & Benchmark & Benchmark \\
\hline $\begin{array}{l}\text { High Price-Adjustment } \\
\text { Cost }\end{array}$ & $\ln c_{t}+1.76\left(1-h_{t}\right)$ & $\begin{array}{l}\eta=0.75 \\
\phi^{\text {pre } 79}=103.21, \phi^{\text {post } 79}=104.65\end{array}$ & Benchmark & Benchmark \\
\hline High Markup & $\ln c_{t}+1.65\left(1-h_{t}\right)$ & $\begin{array}{l}\eta=0.26 \\
\phi^{\text {pre } 79}=2.62, \phi^{\text {post } 79}=2.66\end{array}$ & $\frac{\theta}{\theta-1}=1.17$ & Benchmark \\
\hline $\begin{array}{l}\text { Low Inflation Weight } \\
\text { Pre-1979 }\end{array}$ & $\ln c_{t}+1.76\left(1-h_{t}\right)$ & $\begin{array}{l}\eta=0.61 \\
\phi^{\text {pre79}}=35.2, \phi^{\text {post } 79}=35.7\end{array}$ & Benchmark & $\begin{array}{l}\text { Pre-79: Modified CGG } \\
\text { Post-84: CGG }\end{array}$ \\
\hline
\end{tabular}

The frequency of price adjustment is given by $\eta$. Thus, for example, the fraction of firms that adjust price each quarter is given by $(1-\eta)$. We map the frequency of price adjustments to the price-adjustment cost, $\phi$, using the fact that the Calvo and the convex price-adjustment cost models have the same reduced form for inflation. This implies that $\frac{(1-\eta)(1-\beta \eta)}{\eta}$ in the Calvo model equals $\frac{\theta-1}{\phi \pi^{2}}$ in the convex price-adjustment cost model. Since we assume different steady-state inflation rates pre-1979 and post-1979, we obtain two different values for $\phi$. 
Figure 1

100*Standard deviation hp-filtered real GDP, 8-quarter rolling window

STD HP-filtered Real GDP

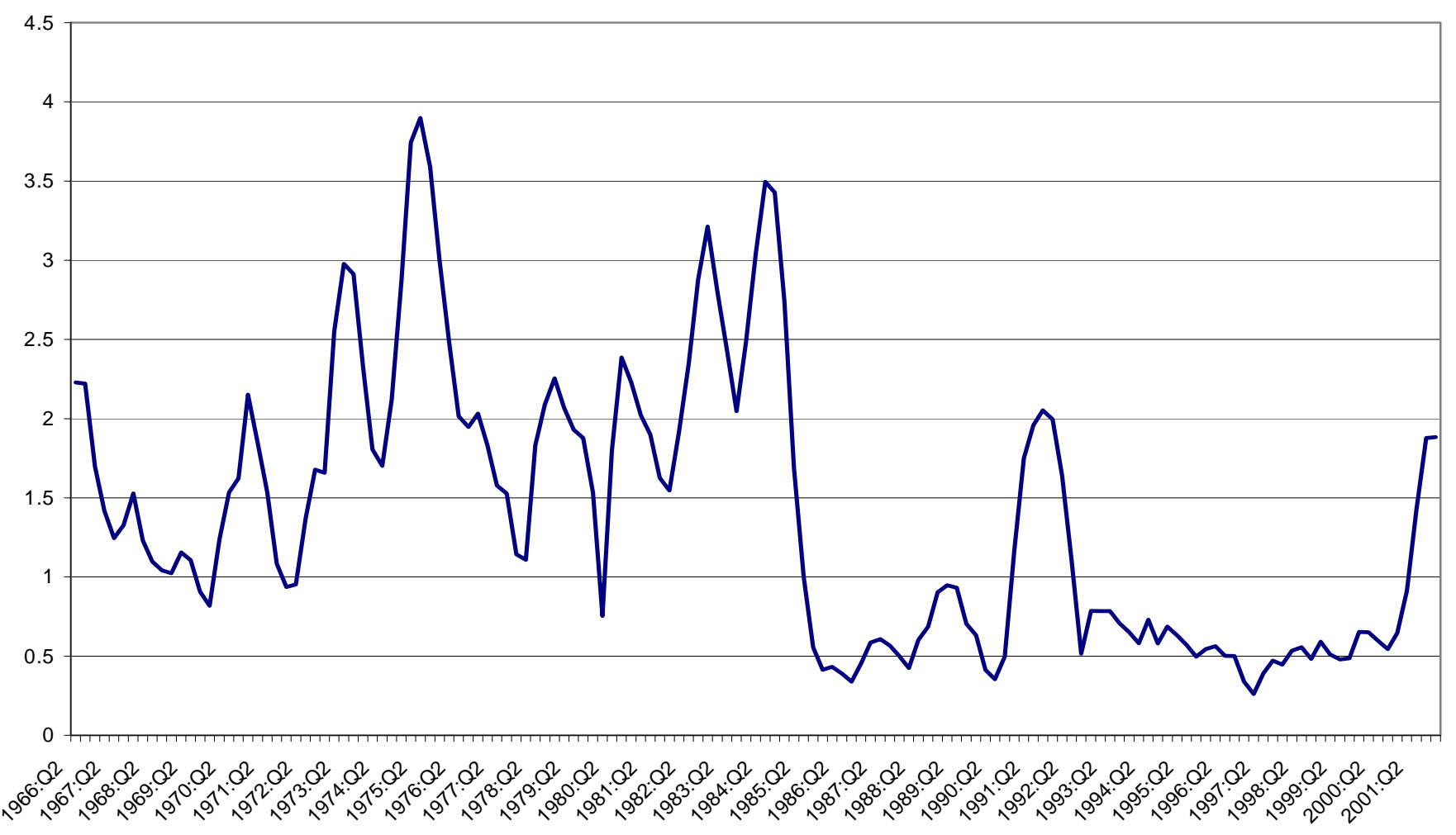


Figure 2

Standard Deviation of HP-filtered $\Delta \ln \left(P_{t}\right)$, 8-quarter rolling window

\section{STD GDP Deflator Inflation}

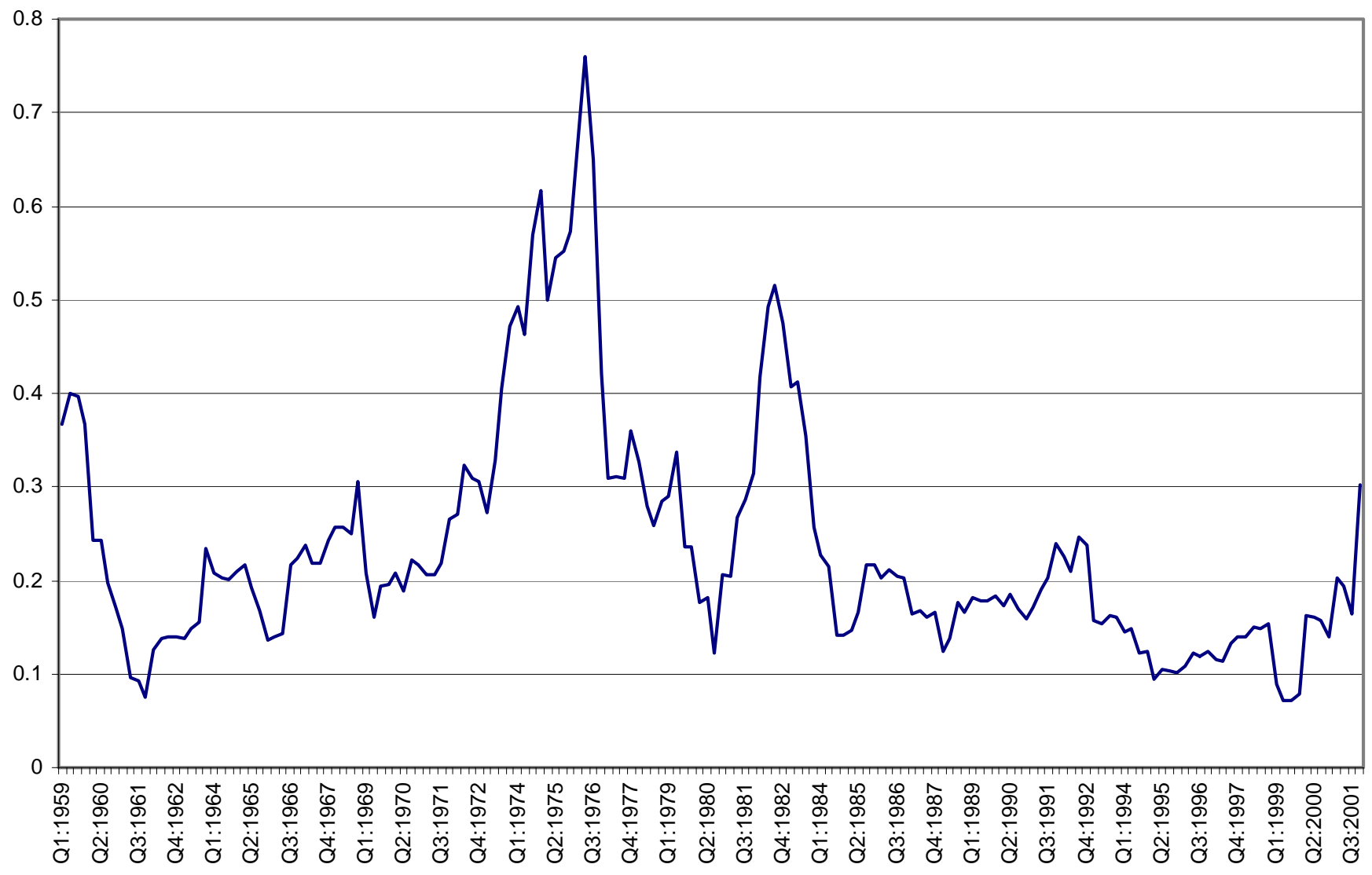


Figure 3. Responses to a Positive TFP Shock Under Alternative Monetary Policies (in \%)

PRE-1979

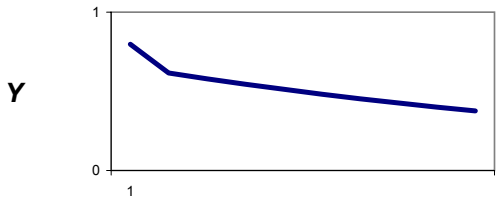

$\mathbf{T}$

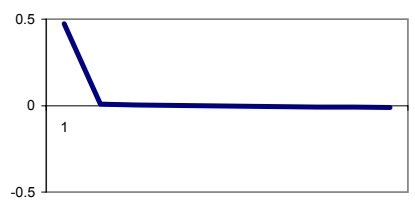

$N R$

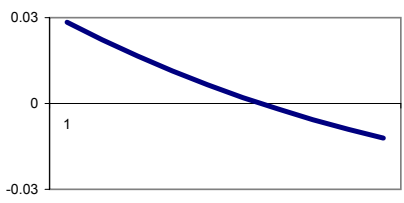

$R R$

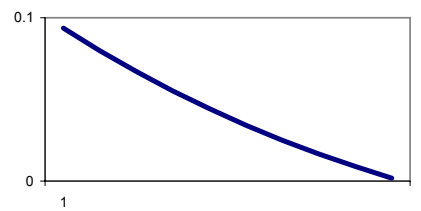

G

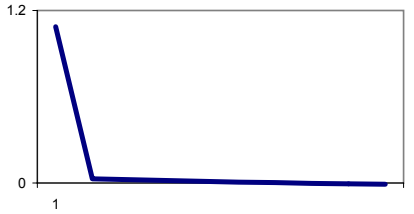

C

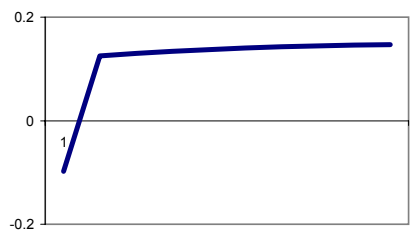

$\boldsymbol{H}$

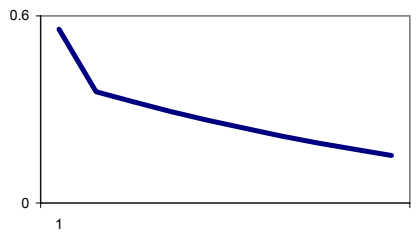

POST-1984
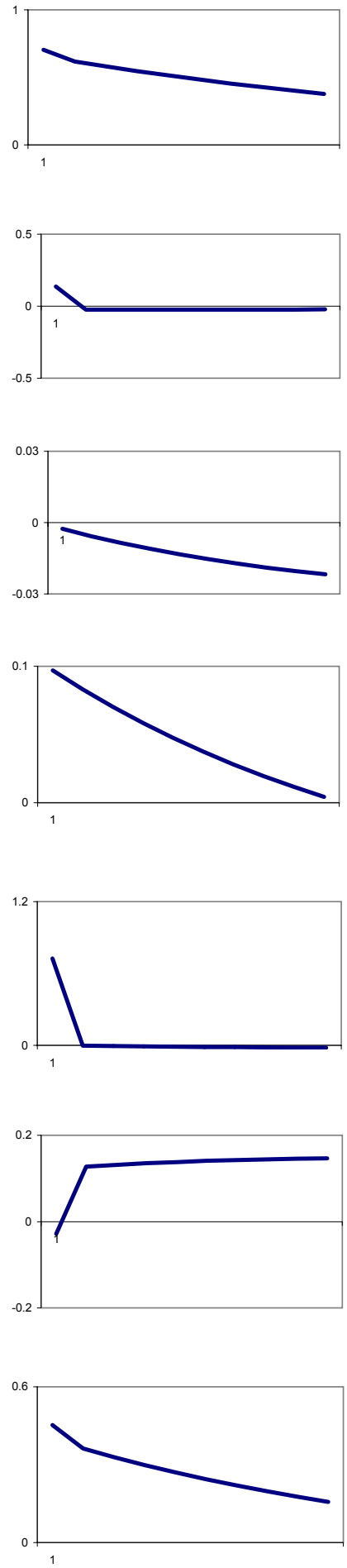

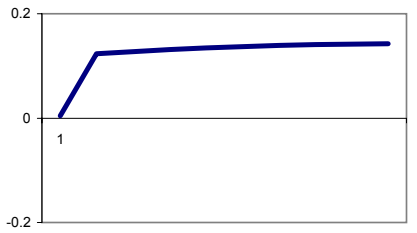

OPTIMAL POLICY
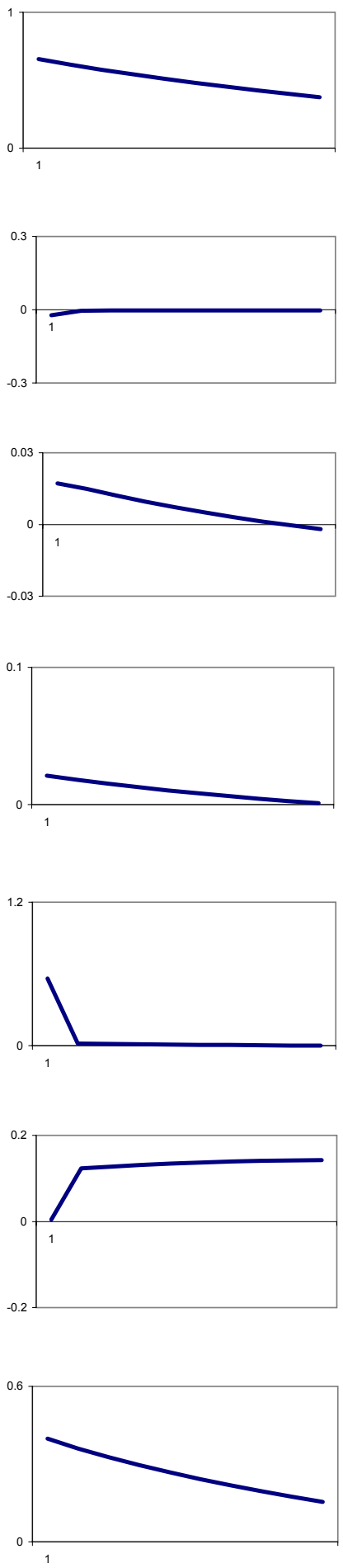

The first two columns report the response of the economy under our benchmark calibration. The interest-rate rule for the pre-1979 period is the rule estimated by Orphanides (2001) for the period 1966-1979, while the rule for the post-1979 period is the one estimated by Clarida, Gali, and Gertler (2000) for the period 1983-1996. See Table 4 for details. 
Figure 4. Responses to a Positive TFP Shock Under Alternative Monetary Policies (in \%)

PRE-1979

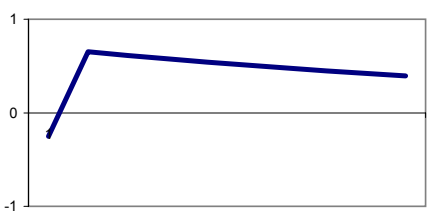

Tा

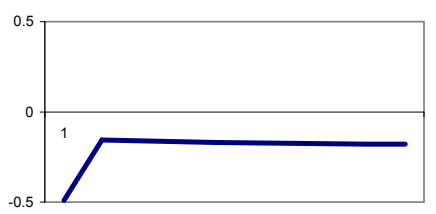

NR

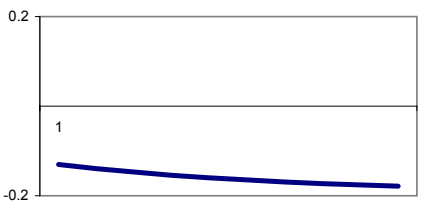

$R R$

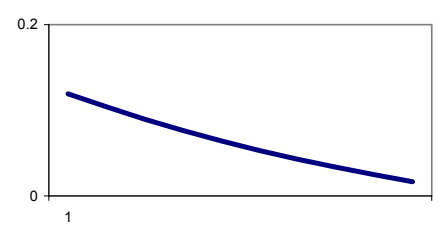

G

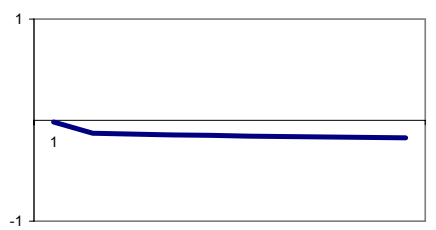

C

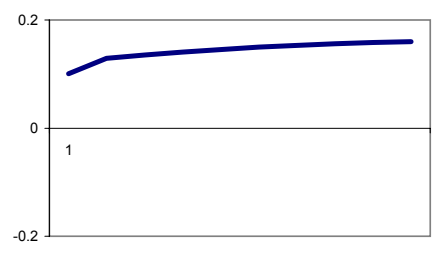

H

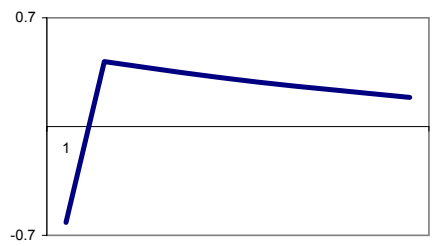

POST-1984
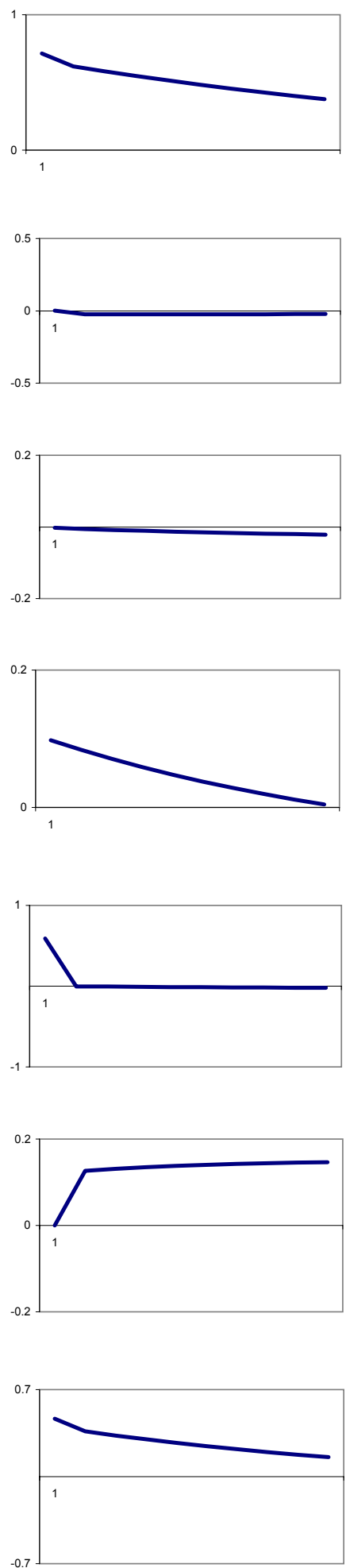

OPTIMAL POLICY
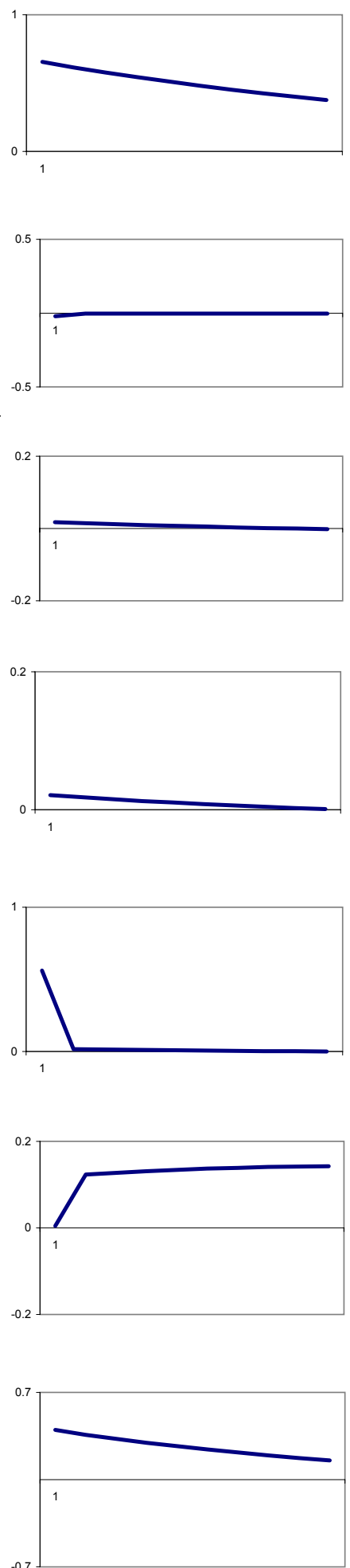

The first column reports the response of the economy under our modified Clarida, Gali, and Gertler (2000) rule for the pre-1979 period. The second column shows the interest-rate rule under our benchmark model. See Table 4 for details. 